Acid Chlorides.--The diacid potassium salt was treated with phosphorus pentachloride, in the presence of a little phosphorus oxychloride, etc. The crude acid chloride obtained was an oily paste which would not solidify. It was dissolved in carbon tetrachloride, treated with a little dry calcium chloride in order to dry it more completely, decolorized with a little bone-black, filtered, and the filtrate allowed to evaporate slowly. Needles were obtained which upon recrystallization melted at $147^{\circ}$. The mother liquor gave an oily residue which could not be crystallized from ligroin, in which it was not very soluble, even when the solution was cooled to $-20^{\circ}$ for several hours. Distillation in a vacuum on a small scale was tried but not with much success. The acid chloride which melted at $I 47^{\circ}$ was treated with strong ammonia and long thread-like needles were obtained which melted at $277^{\circ}$. The oily acid chloride with ammonia also gave needles but they were coarser in structure. It is quite possible that one of these compounds was the ammonium salt of 4-nitro-5-carbamylbenzoic sulphinide and the other the ammonium salt of 2-cyan-4-carbamyl-5-nitrobenzenesulphonic acid. Investigation is in process to clear up this and other obscure points brought out in this work.

UNIVERStTY OF IOWA, IOWA Citr, ia.

\title{
ON THE PREPARATION AND PHYSICAL PROPERTIES OF TETRACHLORETHER.
}

BY FREI NEHER AND WILLIAM FOSTER.

Received January II, Igog.

I. The Preparation of Tetrachlorether. - The following methods for the preparation of $\mathrm{I}, 2,2,2$-tetrachlorether, $\mathrm{CCl}_{3} \mathrm{CHCl} . \mathrm{OC}_{2} \mathrm{H}_{5}$, have been reported: I. From monochlorether and chlorine in the presence of iodine ${ }^{1}$ 2. From dichlorvinylethylether and chlorine. ${ }^{2}$ 3. By treating chloral alcoholate with phosphorus pentachloride. ${ }^{3}$ As is evident, the last named reaction is the one most suitable for the laboratory preparation of pure tetrachlorether. Chloral alcoholate is easily obtainable in any desired quantity and theoretically the only by-products of the reaction are the readily removable phosphorus oxychloride and hydrogen chloride. After the action of the phosphorus pentachloride on the alcoholate was complete, Henry treated the product with water to decompose phosphorus oxychloride, separated the heavy, oily tetrachlorether, washed it with a solution of sodium carbonate, dried over calcium chloride, and distilled. Almost the entire product distilled at $185^{\circ}-190^{\circ}$ and the boiling point was found to be $188^{\circ}$ (uncor.). In a later article ${ }^{5}$ the limits of the main fraction

1 Wurtz and Vogt, 2. Chem., 187 I, 679.

"Godefroy, Jsb. Chem., I886, II 74.

${ }^{3}$ Henry, Ber., 4, Ior, 435. Paternò and Pisati, Jsb. Chem., I872, 303.

- Ber., 4, IOI.

3 Ibid., 4, 436 . 
were given as $185^{\circ}-195^{\circ}$ and the pure liquid, after rectification, was found to boil at $188^{\circ}-190^{\circ}$ at $755 \mathrm{~mm}$. (uncor.). Henry does not state the yield of tetrachlorether he obtained, but repeated trial of his method has shown the yield to be variable and difficult to control, 68 per cent. of the theoretical being about the maximum attainable.

The authors, needing large quantities of tetrachlorether for the preparation of di- and trichlorvinylethylether and of dichloracetal (the preparation and investigation of which will soon be described in THIS JourNaL), undertook to devise some modification in the method of Henry which would insure a better and more consistent yield of the compound. As the result of a large number of experiments a mode of procedure of which the following are the essential steps was adopted:

I. The treatment of the phosphorus pentachloride with an ether solution of chloral alcoholate at a temperature not exceeding $20^{\circ}$.

2. Decomposition of the phosphorus oxychloride with crushed ice and neutralization with a cold solution of sodium hydroxide.

3. Distillation of the product with steam.

These may best be described by citing an experiment as actually carried out. 2 I $8 \mathrm{~g}$. of phosphorus pentachloride and Ioo cc. of dry ether were brought into a flask fitted with a three-hole stopper bearing a calcium chloride tube, a thermometer and a dropping funnel. A solution of $200 \mathrm{~g}$. of chloral alcoholate in $150 \mathrm{cc}$. of dry ether was slowly added through the dropping funnel while the flask was shaken and cooled, the temperature being maintained at $10^{\circ}-20^{\circ}$, mostly at $15^{\circ}-18^{\circ}$. There was almost no evidence of the escape of hydrogen chloride until the temperature approached $20^{\circ}$. After all the chloral alcoholate had been added, the flask and its contents were allowed to stand for about half an hour, when a small amount of phosphorus pentachloride still remained undecomposed. (According to theory $200 \mathrm{~g}$. of chloral alcoholate calls for $215.4 \mathrm{~g}$. phosphorus pentachloride as against the $218 \mathrm{~g}$. used in the experiment.) The contents of the flask were now poured upon crushed ice and the mixture thoroughly stirred and then shaken up in a large separatory funnel. The temperature was kept fairly low while a cold $1: 2$ solution of sodium hydroxide was carefully added until the solution became slightly alkaline, about $600 \mathrm{cc}$. of the sodium hydroxide solution being required. The mixture was next distilled in a strong current of steam, the crude, heavier oil separated from the water distillate, washed twice with water, dried over calcium chloride, and distilled. $37 \mathrm{~g}$. of distillate, consisting mainly of ether, were collected below $180^{\circ}$ and a main fraction of $156 \mathrm{~g}$. from $180^{\circ}-190^{\circ}$, mostly from $188^{\circ}-189^{\circ}$. By working over the first fraction and by extracting the water distillate from the steam distillation with ether, $5.2 \mathrm{~g}$. more of tetrachlorether boiling from $180^{\circ}-190^{\circ}$ were obtained, making a total yield of I6I.2 g., or 73.6 per cent. of the theoretical amount. 
Numerous other preparations gave yields running in every case except one from 55 per cent. to 74 per cent. of the theoretical. The method has since been most successfully employed by the Baker and Adamson Chemical $\mathrm{Co}$. to prepare kilogram quantities of the compound for the authors.

The compound distils without decomposition even at atmospheric pressure and keeps well in a sealed glass tube.

II. The Boiling Point and Specific Gravity of Tetrachlorether.-1. A sample of tetrachlorether prepared as above described and collected from $180^{\circ}-189^{\circ}$, mostly at $188^{\circ}$, was found to have a specific gravity of 1.4195 . This determination, like all others given in this article, was carried out in a Sprengel-Ostwald pycnometer at $18^{\circ}$ and reduced to water at $4^{\circ}$ and to vacuum. On redistillation of this sample a fraction collected at $188^{\circ}$ $189^{\circ}$ showed a specific gravity of 1.4224 .

$$
\begin{array}{ll}
\text { Analysis: calculated for } \mathrm{C}_{4} \mathrm{H}_{6} \mathrm{OCl}_{4} & \mathrm{C}, 22.65 ; \mathrm{H}, 2.86 \\
\text { Found: } & \mathrm{C}, 22.48 ; \mathrm{H}, 2.80
\end{array}
$$

The above preparation of tetrachlorether was kept in a sealed tube for about eight and a half months and then redistilled. It boiled almost constantly at $188^{\circ}$ under a barometric pressure of $756.4 \mathrm{~mm}$. Its specific gravity was found to be 1.4226 .

2. A sample of tetrachlorether from another preparation was collected at $188^{\circ}$ and showed a specific gravity of 1.4224 . The liquid was redistilled and a fraction boiling constantly at $188^{\circ}$ at $755.2 \mathrm{~mm}$. barometric pressure gave a specific gravity of 1,4227 . The boiling point of this sample, which was regarded as especially pure, was determined in an apparatus permitting the mercury of the thermometer to be completely immersed in the vapor of the boiling liquid and found to be $189.4^{\circ}$ at 749 . I mm. (corrected). This is in close agreenent with the value given in Beilstein, $3 \mathrm{Ed}$., Vol. I., p. 296 -namely, $189.7^{\circ}$ at $758.7 \mathrm{~mm}$.

The average of the four determinations of the specific gravity of pure tetrachlorether at $18^{\circ} / 4^{\circ}$ given above is 1.4225 , which is to be taken as the most probable value. Henry ${ }^{1}$ found it to be 1.421 I at $15^{\circ}$; in Beilstein (p. 296) it is given as 1.4379 at $0^{\circ}$ and as 1.4182 at $15.2^{\circ}$.

3. A sample of tetrachlorether that boiled constantly at $189^{\circ}$ under atmospheric pressure was found to boil at $79^{\circ}$ under a pressure of $16 \mathrm{~mm}$.

$$
\begin{array}{ll}
\text { Analysis: calculated for } \mathrm{C}_{4} \mathrm{H}_{6} \mathrm{OCl}_{4} & \mathrm{C}, 22.65 ; \mathrm{H}, 2.86 \\
\text { Found: } & \mathrm{C}, 22.5 \mathrm{I} ; \mathrm{H}, 2.77
\end{array}
$$

Princeton UNIVERsity, Dec 30, 19 os.

\section{2,2-DICHLORVINYLETHYLETHER: ITS PREPARATION FROM TETRACHLORETHER AND ITS PHYSICAL PROPERTIES.}

BY FRED NEHER AND WILLIAM FOSTER.

Received January 14,1909

2,2-Dichlorvinylethylether, $\mathrm{CCl}_{2}: \mathrm{CH} . \mathrm{OC}_{2} \mathrm{H}_{5}$, was first prepared by

${ }^{1}$ Ber., 4, IO2. 